\title{
FAMILY SUPPORT IN IMPROVING INDEPENDENCE OF STROKE PATIENTS
}

\author{
Setyoadi', Tina Handayani Nasution ${ }^{2}$, Amanda Kardinasari ${ }^{3}$ \\ 1,2,3 Nursing School Faculty of Medicine Universitas Brawijaya Malang Indonesia
}

\begin{abstract}
Stroke is a condition which occurs when the brain's blood vessels fail to supply oxygen to the brain cells which caused the brain not functioning properly. As such, stroke patients cannot fully support themselves. However, with constant and proper treatment, it can ease the burden on the patients, minimizing their disability, and reducing their dependence towards others while undergoing an activity. During the recovery phase, family plays an important role, they served as a source of support even during the healing and rehabilitation phase, as such, they are expected to be involved in the process of treatment since the very beginning. The purpose of this study is to identify the correlation of family support with stroke patients' independence in the medical rehabilitation center of Dr. Iskak hospital Tulungagung. In order to focus on the stroke patients, this research uses a purposive sampling method which follows certain predetermined criteria. The research data were collected by using structured interview techniques by utilizing Barthel Index's Instrument and family support instrument. Based on the results of the study, out of 57 respondents, the average score for family support was 87,84 while the stroke patients' independence receives an average score of 81,75. Statistical analysis showed significant value $=0.00$ whereas its sig value $<\alpha=0.05$ These numbers show a strong connection between family support with independence, which means that there is a correlation between family support and stroke patients independence. In conclusion, by giving a better family support the stroke patients can gradually become more independent. Essentially, in order for the stroke patients to gain better condition, it is advised that the paramedics should improve their role in providing education about the importance of family support towards stroke patients' family members as the family plays an important role during the recovery process.
\end{abstract}

Keywords: Stroke, Family Support, Independent

\begin{abstract}
ABSTRAK
Stroke adalah keadaan yang muncul ketika pembuluh darah otak gagal mensuplai oksigen ke sel-sel otak. Pasien stroke tidak dapat sepenuhnya mandiri, namun apabila ditangani dengan baik maka akan meringankan beban penderita, meminimalkan kecacatan dan mengurangi ketergantungan pada orang lain dalam beraktivitas. Keluarga sangat berperan dalam fase pemulihan, sehingga sejak awal perawatan keluarga diharapkan terlibat dalam penanganan penderita. Penelitian ini bertujuan untuk mengetahui hubungan dukungan keluarga dengan kemandirian pasien stroke di instalasi rehabilitasi medik Rumah Sakit Dr. Iskak Tulungagung. Metode penelitian menggunakan purposive sampling. Pengambilan data dilakukan dengan teknik wawancara terstruktur menggunakan kuesioner Barthel Index dan kuesioner dukungan keluarga. Berdasarkan hasil penelitian, dari 57 responden, didapatkan untuk dukungan keluarga skor rata-rata adalah 87,84 . Sementara skor rata-rata kemandirian pasien stroke adalah 81,75 . Hasil uji statistik menunjukkan nilai signifikasi $=0,00$. Nilai sig tersebut $<$ $\alpha=0,05$. Kesimpulan dari penelitian ini adalah terdapat hubungan kuat antara dukungan keluarga dengan kemandirian. Berdasarkan hasil penelitian ini disarankan petugas kesehatan dapat meningkatkan peran dalam memberikan edukasi tentang pentingnya dukungan keluarga kepada pasien stroke karena keluarga berperan penting dalam proses pemulihan.
\end{abstract}

Kata kunci: Stroke, Dukungan Keluarga, Kemandirian

Jurnal Ilmu Keperawatan Vol. 6 No. 1 Mei 2018. Korespondensi : Setyoadi. Jurusan Keperawatan Fakultas Kedokteran Universitas Brawijaya. Jl. Veteran Malang, 65145. Email : setyoadimalang@gmail.com 


\section{PENDAHULUAN}

Stroke adalah keadaan yang muncul ketika pembuluh darah otak gagal mensuplai oksigen ke sel-sel otak (Gillen, 2015). Sel otak akan rusak ketika tidak menerima oksigen dan nutrisi dari darah. Gejala stroke terjadi secara tiba-tiba, dengan kelemahan pada satu sisi tubuh; kebingungan; kesulitan berbicara atau memahami pembicaraan; masalah penglihatan; kesulitan berjalan; kehilangan keseimbangan dan sakit kepala (National Institute of Neurological Disorders and Stroke, 2015).

WHO (2011) menyebutkan terdapat 15.000.000 orang yang di dunia mengalami stroke setiap tahunnya. Pada tahun 2010, prevalensi stroke di seluruh dunia adalah 33 juta jiwa, dengan 16,9 juta jiwa mengalami stroke untuk pertama kali. Dari jumlah tersebut, 5 juta jiwa meninggal dan 5 juta jiwa mengalami cacat permanen (Stroke Association, 2015). Secara global stroke merupakan penyebab utama kedua kematian di negara-negara maju dengan 4,5 juta kematian setiap tahun (Gillen, 2015).

Jumlah penderita Stroke di Indonesia menduduki urutan pertama di Asia dan keempat di dunia, setelah India, Cina, dan Amerika. Jumlah kematian akibat stroke dan penyakit kardiovaskuler diperkirakan akan meningkat mencapai $23 \%$ juta kematian pada tahun 2030 (KEMENKES RI, 2014). Riset Kesehatan Dasar (2013), menunjukkan telah terjadi peningkatan prevalensi stroke di Indonesia dari 8,3 per mil (tahun 2007) menjadi 12,1 per mil (tahun 2013). Prevalensi penyakit Stroke tertinggi di Sulawesi Utara (10,8per mil), Yogyakarta (10,3 per mil),
Bangka Belitung (9,7 per mil) dan DKI Jakarta (9,7 per mil) (KEMENKES RI, 2014).

Menurut BKKBN (2009), Penyakit stroke dan jantung dahulu dianggap sebagai penyakit degeneratif yaitu penyakit untuk usia di atas 60 tahun. Saat ini stroke dapat terjadi pada usia berapa pun dengan $75 \%$ terjadi pada usia diatas 65 tahun dan hampir $25 \%$ terjadi pada usia dibawah 65 tahun. Meningkatnya kejadian stroke pada individu usia 20-25 tahun berdampak terhadap menurunnya tingkat produktivitas (Centers for Disease Control and Prevention, 2010).

Gangguan fungsi akibat stroke secara langsung membuat angka ketergantungan semakin bertambah Gangguan fungsi vital otak seperti gangguan koordinasi, gangguan keseimbangan, gangguan kontrol postur, gangguan sensasi dan gangguan reflek gerak akan menurunkan kemampuan fungsional individu. Stroke merupakan penyebab utama kecacatan pada orang dewasa. Prevalensi kecacatan akibat stroke diperkirakan sekitar 33-460 per 100.000 jiwa (Stroke Association, 2015). Penderita stroke yang bertahan hidup dengan kecacatan merupakan beban ekonomi bagi keluarga dan sistem asuransi kesehatan. Biaya pengobatan dan rehabilitasi pasca-stroke mencapai US\$ 140.000/pasien atau sekitar 1,4 millar rupiah/ pasien (Widjaja, 2015).

Penelitian Cameron et al (2014), sebanyak $50 \%$ dari penderita stroke mengalami kesulitan melakukan aktivitas, termasuk mandi, jalan kaki, naik tangga, melakukan pekerjaan rumah tangga, menyiapkan makanan dan bepergian. Penderita stroke tidak dapat mandiri dan memerlukan bantuan dalam pemenuhan 
kebutuhan sehari-hari. Sepertiga dari penderita stroke memerlukan perawatan lanjutan minimal selama 3 bulan untuk meningkatkan kemampuan mandiri (Langhorne, 2011).

Kemandirian adalah kemampuan untuk memenuhi kebutuhan diri sendiri. Kemandirian mengandung pengertian suatu keadaan dimana seseorang yang memiliki hasrat bersaing untuk maju demi kebaikan dirinya, mampu mengambil keputusan dan inisiatif untuk mengatasi masalah yang dihadapi, memiliki kepercayaan diri dalam mengerjakan tugas-tugasnya, bertanggung jawab terhadap apa yang dilakukan (Mu'tadin, 2002). Pasien stroke tidak dapat sepenuhnya mandiri, namun apabila ditangani dengan baik maka akan meringankan beban penderita, meminimalkan kecacatan dan mengurangi ketergantungan pada orang lain dalam beraktivitas (Mulyatsih \& Ahmad, 2008).

Upaya pencegahan (preventif) dilakukan untuk mengendalikan kejadian penyakit, kematian dan kecacatan. Pencegahan dilakukan dengan meningkatkan kesadaran masyarakat dengan mengenali tanda gejala dan risiko sehingga dapat menentukan langkah-langkah pencegahan yang tepat. Upaya promotif untuk meningkatkan kualitas kesehatan dan mencegah serangan berulang. Upaya kuratif bagi individu yang telah mengalami kecacatan akibat stroke untuk pengobatan dan mencegah komplikasi yang mungkin timbul dan upaya rehabilitatif untuk pengembalian fungsi tubuh (KEMENKES., 2014).

Rehabilitasi pada pasien stroke bertujuan untuk memperbaiki mobilitas dan pencapaian perawatan diri secara mandiri oleh pasien (Bruner \& Suddarth, 2002). Kepatuhan pasien stroke mematuhi dalam rehabilitasi memerlukan dukungan keluarga untuk mencapai hasil fungsional yang maksimal. Keluarga sangat berperan dalam fase pemulihan ini, sehingga sejak awal perawatan keluarga terlibat dalam penanganan penderita (Mulyatsih \& Ahmad, 2008).

Sasaran subjek proses rehabilitasi pada pasien stroke adalah pasien dan keluarga. Proses penyembuhan dan rehabilitasi pasien stroke dapat terjadi dalam waktu lama, yang membutuhkan kesabaran dan ketekunan pasien dan keluarga. Dalam masa rehabilitasi seringkali pasien stroke malas untuk melakukan latihan dalam menjaga mobilitas seperti melakukan latihan rentang gerak, maka dari itu sangat diperlukan dukungan dari keluarga untuk memberikan pengertian kepada pasien dan melatih serta membantu pasien untuk selalu melakukan latihan rentang gerak (Bruner \& Suddarth, 2002).

Friedman, (1981), dalam Setiadi, (2010), peran keluarga yaitu mampu mengenal masalah kesehatan, mengambil keputusan untuk mengambil tindakan yang tepat bagi keluarga, memberikan perawatan kepada anggota keluarga yang sakit, yang tidak dapat membantu diri karena cacat atau umur terlalu muda, mempertahankan suasana rumah yang menguntungkan untuk kesehatan dan perkembangan kepribadian dan pemanfaatan fasilitas kesehatan yang ada. Keluarga bersifat mendukung selama masa penyembuhan dan pemulihan klien. Dukungan dari keluarga yang kurang dapat mempengaruhi kurangnya keberhasilan rehabilitasi, penyembuhan atau pemulihan 
(Friedman, 2003). Anggota keluarga sangat mempengaruhi respon pasien terhadap penyakit yang dideritanya dan keluarga ikut berperan terhadap keberhasilan dan kegagalan upaya pemulihan.

Berdasarkan hasil studi pendahuluan, pasien stroke rawat jalan di instalasi rehabilitasi medik rumah sakit Dr. Iskak Tulungagung mencapai 709 pada tahun 2014. Rumah sakit mencatat stroke merupakan penyakit urutan ke-4 di instalasi rehabilitasi medik. Dalam rentang bulan Januari hingga November 2015, jumlah pasien stroke di Instalasi Rehabilitasi Medik Rumah Sakit Dr. Iskak berjumlah 805. Ketika pasien datang, pasian selalu ditemani dengan keluarga, karena keterbatasan yang dimiliki. Keluarga mempunyai harapan bahwa pasien dapat sembuh seperti semula. Berdasarkan latar belakang diatas maka penulis ingin meneliti bagaimana pengaruh dukungan keluarga dengan kemandirian pasien stroke di instalasi rehabilitasi medik Rumah Sakit Dr. Iskak Tulungagung.

\section{METODE}

Penelitian ini menggunakan deskriptif korelasional dengan metode pendekatan cross sectional. Populasi dalam penelitian ini adalah seluruh penderita pasien stroke di Instalasi Rehabilitasi Medik Rumah Sakit Dr. Iskak Tulungagung. Besar sampel yang didapatkan sebesar 57 responden yang diambil dengan metode purposive sampling. Variabel independen adalah dukungan keluarga pada pasien stroke. Variabel dependen adalah kemandirian pada pasien stroke. Data dianalisa mengunakan uji korelasi pearson.

\section{HASIL}

Table 1. Data Demografi Responden

\begin{tabular}{|l|l|c|c|}
\hline \multicolumn{2}{|c|}{ Karakteristik } & f & $\%$ \\
\hline \multirow{2}{*}{$\begin{array}{l}\text { Jenis } \\
\text { kelamin }\end{array}$} & perempuan & 22 & $38,60 \%$ \\
\cline { 2 - 4 } $\begin{array}{l}\text { Status } \\
\text { pernikahan }\end{array}$ & Laki-laki & 35 & $61,40 \%$ \\
\cline { 2 - 4 } & Janda & 51 & $89.48 \%$ \\
\cline { 2 - 4 } & Duda & 5 & $8.77 \%$ \\
\hline \multirow{5}{*}{ Komlikasi } & Tidak ada & 47 & $1.75 \%$ \\
\cline { 2 - 4 } & DM & 6 & $10.53 \%$ \\
\cline { 2 - 4 } & Jantung & 4 & $7.02 \%$ \\
\hline Tinggal & Keluarga Inti & 48 & $84.21 \%$ \\
\cline { 2 - 4 } & Keluarga & 9 & $15.79 \%$ \\
& Besar & & \\
\hline Caregiver & Pasangan & 37 & $64.91 \%$ \\
\hline \multirow{2}{*}{} & Anak & 11 & $19.30 \%$ \\
\hline \multirow{2}{*}{} & Pasangan, & 9 & $15.79 \%$ \\
& Anak & & \\
\hline
\end{tabular}

Berdasarkan tabel 1 sebagian besar responden berjenis kelamin laki-laki yaitu 35 orang dengan presentase $61,40 \%$. Sebagian besar responden pasien stroke berstatus menikah dengan jumlah 51 orang atau sekitar $89,48 \%$. Sebagian besar responden tidak mempunyai penyakit komplikasi dengan jumlah 47 orang $(82,46 \%)$. Paling banyak atau $84,21 \%$ responden tinggal bersama keluarga inti yang terdiri dari pasangan dan anak, sedangkan sisanya tinggal bersama keluarga besar yang terdiri dari pasangan, anak, menantu dan cucu. Responden di rawat oleh pasangan dengan jumlah 37 orang atau sekitar $64,91 \%$.

\section{Table 2. Data Usia dan Lama Menderita}

\begin{tabular}{|l|c|c|c|}
\hline \multicolumn{1}{|c|}{ Variabel } & Min & Max & Rata-Rata \\
\hline Usia & $\begin{array}{c}37 \\
\text { tahun }\end{array}$ & $\begin{array}{c}83 \\
\text { tahun }\end{array}$ & 58 tahun \\
\hline $\begin{array}{l}\text { Lama } \\
\text { Menderita } \\
\text { Stroke }\end{array}$ & $\begin{array}{c}1 \\
\text { bulan }\end{array}$ & $\begin{array}{c}80 \\
\text { bulan }\end{array}$ & 18 bulan \\
\hline
\end{tabular}


Berdasarkan tabel 2 dapat diketahui bahwa muda adalah 37 tahun sedangkan usia paling tua adalah 83 tahun. Dengan usia rata-rata adalah 58 tahun. lama responden terserang stroke adalah rentang 1 bulan hingga 80 bulan. Dengan rata-rata lama terserang 18 bulan.

\section{Dukungan Keluarga}

Tabel 3. Distribusi Karakteristik Dukungan Keluarga

\begin{tabular}{|c|c|c|c|c|c|}
\hline Variabel & N & Sd & Means & Min & Max \\
\hline $\begin{array}{c}\text { Dukungan } \\
\text { keluarga }\end{array}$ & 57 & 9,53 & 87,84 & 62 & 100 \\
\hline
\end{tabular}

Berdasarkan tabel 3 dapat diketahui hasil skor variabel dukungan keluarga berdasarkan kriteria yang telah ditentukan. Dari 57 responden, didapatkan skor tertinggi adalah 100 dan skor terendah adalah 67 . Rata-rata dukungan keluarga mendapatkan skor 87,84 yang berarti dukungan keluarga baik.

\section{Tabel 4. Distribusi Jenis Dukungan}

\section{Keluarga}

\begin{tabular}{|c|l|c|c|c|c|c|c|}
\hline \multirow{2}{*}{ No } & \multirow{2}{*}{$\begin{array}{c}\text { Jenis } \\
\text { Dukungan } \\
\text { Keluarga }\end{array}$} & \multicolumn{2}{|c|}{ Baik } & \multicolumn{2}{c|}{ Cukup } & \multicolumn{2}{c|}{ Kurang } \\
\cline { 2 - 8 } & $\mathbf{f}$ & $\%$ & $\mathbf{f}$ & $\%$ & $\mathbf{f}$ & $\%$ \\
\hline 1 & $\begin{array}{l}\text { Informa- } \\
\text { sional }\end{array}$ & 5 & 89,47 & 6 & 10,53 & 0 & 0 \\
\hline 2 & $\begin{array}{l}\text { Penghar- } \\
\text { gaan }\end{array}$ & 4 & 77,20 & 10 & 17,54 & 3 & 5,26 \\
\hline 3 & $\begin{array}{l}\text { Instrum- } \\
\text { ental }\end{array}$ & 5 & 87,72 & 7 & 12,28 & 0 & 0 \\
\hline 4 & $\begin{array}{l}\text { Emosion- } \\
\text { al }\end{array}$ & 5 & 89,47 & 6 & 10,53 & 0 & 0 \\
\hline
\end{tabular}

Berdasarkan tabel 4 di atas diketahui jenis dukungan keluarga yang diterima pasien stroke terbanyak adalah dukungan informasional $(89,47 \%)$ dan dukungan emosional $(89,47 \%)$. Jenis dukungan keluarga yang paling sedikit diberikan adalah dukungan penghargaan $(77,2 \%)$.
Tabel. 5 Frekuensi

Responden Berdasarkan Kemandirian

\begin{tabular}{|c|c|c|c|c|c|}
\hline Variabel & $\mathbf{N}$ & sd & Means & Min & Max \\
\hline Kemandirian & 5 & 14,8 & 81,75 & 15 & 100 \\
& 7 & 6 & & & \\
\hline
\end{tabular}

Tabel di atas adalah hasil variabel kemandirian berdasarkan kriteria yang telah ditentukan. Dari 57 responden, didapatkan skor tertinggi adalah 100 dan skor terendah 15. Rata-rata mendapatkan skor 81,75 yang berati ketergantungan sedang.

Hubungan Dukungan Keluarga dengan Kemandirian Pasien Stroke

Tabel 6. Analisis Hubungan Dukungan Keluarga dengan Kemandirian

\begin{tabular}{|l|c|c|c|}
\hline Variabel & rhitung & sig & Keterangan \\
\cline { 1 - 1 } $\begin{array}{l}\text { Dukungan } \\
\text { Keluarga }\end{array}$ & 0,737 & 0,00 & $\begin{array}{c}\text { Ada } \\
\text { Hubungan }\end{array}$ \\
\cline { 1 - 1 } Kemandirian & & & \\
\hline
\end{tabular}

Berdasarkan hasil analisis yang tertera pada tabel di atas, diperoleh nilai $r_{\text {hitung }}$ sebesar 0,737 dengan nilai signifikansi= 0,000 . Nilai sig tersebut $<\alpha=0,05$ sehingga diputuskan $\mathrm{H}_{1}$ diterima. Dapat diartikan bahwa terdapat hubungan antara dukungan keluarga dan kemandirian dan hubungan ini termasuk kuat. Nilai koefisien yang bertanda positif (+) mempunyai makna apabila dukungan keluarga responden baik, maka responden akan semakin mandiri.

\section{PEMBAHASAN}

\section{Dukungan Keluarga pada Pasien Stroke}

Hasil penelitian dukungan keluarga dari 57 pasien stroke di Instalasi Rehabilitasi Medik Rumah Sakit Dr. Iskak menunjukkan bahwa sebagian besar pasien stroke 
mendapatkan dukungan keluarga yang baik yaitu sebanyak 50 orang $(87,72 \%)$, dukungan keluarga yang cukup sebanyak 7 orang $(12,28 \%)$, dan tidak ada responden yang berada pada kategori dukungan keluarga kurang. Hasil penelitian ini sejalan dengan penelitian yang dilakukan oleh (Endriyani, 2011) dukungan keluarga pada pasien post stroke menyatakan bahwa $82,5 \%$ pasien stroke mendapatkan dukungan keluarga "baik" dan 18,5\% pasien mendapatkan dukungan keluarga "cukup".

Dukungan keluarga adalah suatu bentuk hubungan interpersonal yang terdiri atas sikap, tindakan, dan penerimaan terhadap anggota keluarga, sehingga anggota keluarga ada yang memperhatikan (Friedman, 2010). Dukungan keluarga yang baik pada pasien stroke di instalasi rehabilitasi medik rumah sakit Dr. Iskak menunjukkan bahwa keluarga senantiasa ikut berupaya dalam hal penyembuhan dan pemulihan pasien. Sebanyak 57 keluarga (100\%) pasien datang bersama keluarga.

Sebanyak $84,21 \%$ pasien stroke tinggal bersama keluarga inti yang terdiri dari ayah, ibu dan anak. Keluarga merupakan bagian dari pasien yang paling dekat dan tidak dapat dipisahkan. Pasien akan merasa senang dan tentram apabila mendapatkan perhatian dan dukungan dari keluarganya, karena dengan dukungan tersebut akan menimbulkan kepercayaan diri untuk menghadapi atau mengelola penyakitnya dengan lebih baik (Karunia, E., 2016).

Berdasarkan hasil penelitian, pasien stroke yang berstatus menikah sebanyak 51 responden $(89,47 \%)$. Status menikah menguntungkan bagi kesembuhan pasien stroke karena mendapatkan perhatian dan perawatan dari pasangan. Caregiver pasien stroke dalam penelitian ini sebagian besar atau 37 orang $(64,91 \%)$ adalah pasangannya. Pasangan hidup memiliki fungsi sebagai supporting dalam berbagai hal misalnya emosi, problem solving, keuangan, maupun pengasuhan (Papalia \& Feldman, 2009). Pernyataan tersebut sejalan dengan penelitian Pratita, 2012 yang menyatakan dukungan pasangan memiliki pengaruh terhadap kepatuhan proses pengobatan diabetes melitus.

Menurut (Friedman, 2010), jenis dukungan keluarga dibagi menjadi 4 komponen yaitu dukungan informasional, dukungan penghargaan, dukungan instrumental dan dukungan emosional. Berdasarkan hasil penelitian, jenis dukungan keluarga yang paling banyak diterima adalah dukungan informasional dan dukungan emosional. Selanjutnya dukungan instrumental dan jenis dukungan yang paling sedikit didapatkan adalah dukungan penghargaan.

Jenis dukungan informasional paling banyak diterima pasien stroke dalam penelitian ini yaitu sebanyak 51 responden $(89,47 \%)$. Berbeda dengan penelitian yang dilakukan oleh (Wurtuningsih, 2012) yang menyimpulkan bahwa dalam dukungan informasional tidak banyak diberikan keluarga karena takut menyebabkan pasien banyak memikirkan tentang penyakitnya. Dukungan informasional merupakan tanggung jawab bersama termasuk dalam memberikan solusi dari masalah, nasehat atau arahan, dan memberikan informasiinformasi penting yang dibutuhkan pasien dalam proses penyembuhan. Pasien 
mendapatkan dukungan informasional yang baik karena saat ini sangat mudah mengakses informasi mengenai suatu penyakit dari dokter, perawat, terapis, media cetak dan media elektronik (Notoadmojo, 2007). Berdasarkan jawaban pertanyaan dalam kuesioner, sekitar 91,23\% keluarga pasien selalu mengingatkan pasien untuk kontrol ke rumah sakit. Selain itu, keluarga pasien stroke di instalasi rehabilitasi medik selalu memberikan nasehat tentang makanan dan gaya hidup yang bisa memicu terjadinya stroke, memberikan informasi upaya penyembuhan, mengingatkan untuk kontrol dan latihan gerak tubuh.

Dukungan emosional meliputi bentuk dukungan keluarga dalam bentuk perhatian, kasih sayang, dan simpati (Bomar, 2004; Kaakinen, et al., 2015. Memberikan dukungan emosional kepada keluarga dapat memberikan perlindungan psikososial dan dukungan terhadap anggotanya. Hasil penelitian menunjukkan bahwa sebanyak 51 responden $(89,47 \%)$ telah mendapatkan dukungan emosional yang baik dari keluarga. Dukungan emosional ditunjukkan keluarga dengan selalu mendengarkan keluhan-keluhan yang diungkapkan pasien, menjaga perasaan agar tidak tersinggung, menghibur saat pasien sedih dan mengungkapkan rasa sayangnya dengan perkataan maupun perbuatan.

Berdasarkan hasil penelitian didapatkan bahwa 50 pasien $(87,72 \%)$ mendapatkan dukungan instrumental yang baik. Hasil ini menunjukkan bahwa keluarga telah menjalankan fungsi perawatan kesehatan dan fungsi ekonomi keluarga dengan baik. Fungsi perawatan kesehatan dapat berupa menyediakan kebutuhan sehari-hari seperti makan, pakaian, tempat istirahat yang nyaman dan membantu pasien minum obat. Fungsi ekonomi keluarga berupa penyediaan finansial yang cukup untuk perawatan dan pengobatan.

Dukungan penghargaan bertindak sebagai umpan balik terhadap apa yang sudah individu lakukan. Hasil penelitian menunjukkan bahwa sebanyak 44 pasien $(77,2 \%)$ telah mendapatkan dukungan dengan baik. Dukungan penghargaan ditunjukkan dengan keluarga selalu memberikan pujian apabila pasien stroke mengalami kemajuan, memberikan semangat dan tetap meminta pendapat kepada penderita atas pemecahan masalah keluarga sehingga pasien tetap merasa dihargai.

\section{Kemandirian Pasien Stroke di Instalasi Rehabilitasi Medik Rumah Sakit Dr. Iskak Tulungagung}

Kemandirian adalah kemampuan diri sendiri dalam mencukupi kebutuhan tanpa memerlukan bantuan dari orang lain. Stroke menyebabkan gangguan yang mempunyai dampak terhadap kemandirian seseorang. Kemandirian seseorang dinilai dengan menggunakan instumen Barthel Index yang meliputi 10 aktivitas yaitu makan, mandi, merawat diri, berpakaian, buang air besar, buang air kecil, penggunaan toilet, berpindah, mobilitas dan menggunakan tangga (Karunia, Esa. 2016)

Prevalensi Ketergantungan akibat stroke diperkirakan sekitar 33-460 per 100.000 penduduk (Javier, 2012). Hasil penelitian ini, dari 57 pasien stroke mengalami gangguan kemandirian dengan kriteria 
ketergantungan sedang 41 pasien $(71,93 \%)$, ketergantungan ringan 7 pasien (12,28\%), mandiri 4 pasien $(7,02 \%)$ dan ketergantungan total 1 pasien. Penelitian ini sejalan dengan penelitian Endriyani, 2011 bahwa sebagian besar pasien stroke berada pada kondisi ketergantungan sedang sebanyak $70,4 \%$ responden.

Menurut (Javier, 2012), 15\% hingga 30\% penderita stroke memiliki gangguan fisiologis permanen yang mengakibatkan penderitanya mengalami gangguan kemandirian dalam melakukan kegiatan. Kemandirian pada pasien stroke juga dipengaruhi oleh beberapa faktor yang dapat memperparah kecacatan yaitu usia, tingkat keparahan stroke, kecacatan, disfungsi kognitif, depresi pasca stroke dan tidak adanya dukungan sosial (Carod, 2005). Pasien Carod, 2005 stroke di instalasi rehabilitasi medik rumah sakit Dr. Iskak didominasi rentang usia 56-65 tahun yaitu sebanyak 29 pasien $(50,87 \%)$ dan dihubungkan dengan kondisi kemandirian yang paling banyak ditemui adalah ketergantungan sedang (71,93\%). Data dalam penelitian ini sesuai dengan hasil penelitian (Karunia, 2016), yang mengungkapkan bahwa usia berperan dalam kemandirian pasien stroke.

Berdasarkan karakteristik jenis kelamin, jumlah responden laki-laki sebanyak 35 orang $(67 \%)$, sementara perempuan 22 orang $(35,60 \%)$. Hasil penelitian ini sesuai dengan data (KEMENKES, RI, 2013 dan Pinzon \& Ahanti, 2010) bahwa laki-laki lebih mudah terkena stroke karena mempunyai angka faktor resiko yang lebih tinggi (hipertensi, merokok dan alkohol). Pada penelitian (Cameron et al. 2014), tidak ditemukan perbedaan kemandirian antara laki-laki dengan perempuan, hal ini disebabkan oleh adanya manifestasi yang dialami pasien stroke yaitu kelemahan fisik memiliki dampak yang sama terhadap ketidak-mampuan dalam memenuhi aktivitas sehari-hari seperti makan, mandi, merawat diri, berpindah dan lain-lain.

Berdasarkan pertanyaan kuesioner dalam penelitian ini, paling banyak (11 responden) lama stroke 12 bulan dengan tingkat kemandirian $72,72 \%$ ketergantungan sedang. Berdasarkan analisa lamanya menderita stroke dan tingkat kemandirian pada penelitian ini, lama stroke tidak mempengaruhi kemandirian pasien. Menurut Irfan, 2012 berat parahnya stroke tergantung pada bagian mana yang mengalami kerusakan akibat pengumpulan darah atau perdarahan, besar atau luasnya kerusakan dan seberapa banyak yang mampu diatasi.

\section{Analisa Dukungan Keluarga dengan Kemandirian Pasien Stroke di Instalasi Rehabilitasi Medik Rumah Sakit Dr. Iskak Tulungagung}

Berdasarkan hasil analisis korelasi pearson diperoleh nilai $r_{\text {hitung }}$ sebesar 0,737 dengan nilai signifikansi $=0,00$. Nilai sig tersebut $<\alpha=0,05$. Hubungan ini termasuk kuat, maka dapat disimpulkan terdapat hubungan antara dukungan keluarga dengan kemandirian pada pasien stroke. Berdasarkan hasil tersebut dapat diketahui apabila dukungan keluarga responden baik, maka responden akan semakin mandiri.

Hasil penelitian ini sejalan dengan penelitian sebelumnya oleh Rosiana (2012) 
yang berjudul "Hubungan Dukungan Keluarga dengan Kepatuhan Menjalani Fisioterapi pada Klien Pasca Stroke di Instalasi Rehabilitasi Medik RSUD Sleman Yogyakarta". Penelitian Rosiana, (2012), menyebutkan bahwa sebagian besar responden telah memperoleh dukungan keluarga yang baik. Kesesuaian penelitian ini dengan penelitian sebelumnya dapat ditunjukkan bahwa semakin tinggi atau semakin baik dukungan keluarga, maka semakin patuh pasien stroke dalam menjalani rehabilitasi dan peningkatan kemandirian.

Menurut peneliti, apabila keluarga memberikan dukungan yang baik kepada pasien stroke maka kemandirian pasien stroke akan meningkat. Berdasarkan hasil kuesioner dalam penelitian ini keluarga selalu optimis pasien stroke akan pulih kembali dengan melakukan latihan dan rajin kontrol. Sehingga pasien stroke akan merasa termotivasi dan semangat melakukan latihan dan menjalani pengobatan. Penelitian ini sejalan (Friedman et al., 2010) yang mengatakan bahwa dukungan keluarga terbukti berhubungan dengan menurunnya mortalitas, lebih mudah sembuh dari sakit, fungsi kognitif, fisik dan kesehatan emosi.

Penelitian ini juga sesuai dengan penelitian Kosassy (2011), yang menyatakan terdapat hubungan peran keluarga dalam merawat dan memotivasi pasien pasca stroke dengan kepatuhan penderita dalam mengikuti pengobatan dan pelaksanaan rehabilitasi. Keluarga adalah unit yang paling dekat dengan pasien yang memiliki peran sebagai motivator atau pendukung serta sebagai edukator bagi anggota keluarga lain dalam melaksanakan program kesehatan secara mandiri. Jika tidak ada dukungan dari keluarga, maka keberhasilan pemulihan (rehabilitasi) semakin kecil. Oleh karena itu, dukungan keluarga sangat diperlukan dalam mendampingi pasien stroke mengikuti rehabilitasi (Friedman, et al., 2010).

\section{SIMPULAN}

Berdasarkan hasil penelitian dan pembahasan maka dapat diambil kesimpulan dukungan keluarga pasien stroke di Instalasi Rehabilitasi Medik Rumah Sakit Dr. Iskak mayoritas memiliki dukungan keluarga yang baik yaitu sebanyak 87,72\%. Kemandirian pasien stroke sebagian besar masuk dalam klasifikasi ketergantungan sedang yaitu sebanyak $71,93 \%$. Terdapat hubungan positif dukungan keluarga dengan kemandirian pasien stroke, sehingga semakin baik dukungan keluarga maka semakin mandiri pasien stroke di Instalasi Rehabilitasi Medik Rumah Sakit Dr. Iskak. (sig $<\alpha=0,05$; p value $=0,00, r=0,737)$.

Bagi Petugas Kesehatan Diharapkan petugas kesehatan dapat meningkatkan peran dalam berkolaborasi dengan keluarga dan pasien dalam melakukan latihan dan menjaga mobilitas seperti melakukan latihan rentang gerak. Keluarga dan pasien dapat saling memberikan dukungan dalam meningkatkan fungsi fisiologis tubuh pasien stroke dirumah. Saran penelitian selanjutnya yang berhubungan dengan kemandirian pasien stroke dengan faktor-faktor lain yang belum pernah diteliti seperti kondisi ekonomi, jenis stroke dan tingkat kecacatan. 


\section{DAFTAR PUSTAKA}

Ahmad, M., Graham, K.M. Tanpa Tahun. Inflamation After Stroke: Mechanism and Therapeutic Approaches. Trans Strooke Res, 1010;1 (2): 74-75

American Stroke Association, 2012. About Stroke, (Online), (http://www.stroke association.org/STROKEORG/AboutStroke/ TypesofStroke/Types-of-Stroke UCM 308531 SubHomePage.jsp\#, diakses November 2015)

Baehr, M., Frostcher, M, 2007. Diagnosis Topik Neuroligi DUUS: Anatomi. Fisiologi Tanda dan Gejala. Jakarta:Penerbit Buku Kedokteran EGC.

BKKBN, 2009. (Online), (http://nad.bkkbn. go.id/, diakses November 2015).

Black, J. M., \& Hawks, J. H. 2009. Medical Surgical Nursing Clinical Management For Positive Outcomes. 8th edition. St. Louis, Missouri:Saunders Elsevier

Bomar. 2004. Promoting Health in Families: Applying Family Research and Theory to Nursing Practice. Elsevier Health Sciences. Philadhelpia. Pensylvania.

Brunner and Suddarth. (2002). Buku Ajar Keperawatan Medikal Bedah, edisi 8 volume 2. Jakarta : EGC.

Cameron et al. 2014. Randomized Clinical Trial of the Timing It Right Stroke Family Support Program:Research Protocol. BMC Health Services Research 2014 14:18.

CDC, 2014. Stroke Maps and Data Sources, (Online), (http://www.cdc.gov/stroke/ maps_data.html, diakses November 2015).

CDC, 2014. About Stroke, (Online), (http:// www.cdc.gov/stroke/about.html, diakses November 2015).
Dillon, P. M. 2007. Nursing Health Assessment: A Critical Thinking, Case Studies Approach. 2th Edition. Philadelphia: F. A. Davis Company.

Christine, Merlyn. 2010. Hubungan Dukungan Keluarga dengan Respon Cemas Anak Usia Sekolah terhadap Pemasangan Intravena di Rumah Sakit Advent Medan. Skripsi. Tidak dipublikasikan

Cuccurullo，Sara. 2014. Physical Medicine and Rehabilitation Board Review, Third Edition. USA:Demosmedical.

DeLaune, S. C., \& Ladner, P. K. 2002. Fundamental of Nursing: Standards \& Practice. 2nd ed. United States of America: Delmar Thomson Learning, Inc.

DEPKES, 2014. Presiden Resmikan RS Pusat Otak Nasional, (Online), (http:// www.depkes.go.id/article/view/ $201407200001 / p r e s i d e n-r e s m i k a n-r s-$ pusat-otak-nasional.html, diakses November 2014).

Endriyani, Lia. 2011. Hubungan Dukungan Keluarga dengan Kemandirian Activities Of Daily Living Pasien Post Stroke di RSU PKU Muhammadiyah Bantul. Naskah Publikasi.

Karunia, Esa. 2016. Hubungan Antara Dukungan Keluarga Dengan

Kemandirian Activity of Daily Living Pascastroke. Jurnal Berkala Epidemiologi, Vol. 4 No. 2, Mei 2016: 213-224

Friedman, M. 2010. Buku Ajar Keperawatan keluarga : Riset, Teori, dan Praktek. Edisi ke-5. Jakarta: EGC.

Gillen, G. 2015. Stroke rehabilitation. A function-based Approach (Fourth ed.). United States of America: Elsevier. 
Gill, T. M., Guo, Z., \& Allore, H. G. 2006. The Epidemiology Of Bathing Disability In Older Persons. Journal American Geriatrics Society, 54, 1524-1530.

Ginsberg, L. 2007. Lecture notes: Neurologi. Edisi 8 (Terj. dari Lecture Notes: Neurology, $8^{\text {th }}$ Edition, Wardhani, I. R.). Jakarta: Penerbit Erlangga.

Gofir, A. 2009. Managemen Stroke. Yogyakarta: Pustaka Cendekia Press. P.19-20

Grotta James I. Et all. 2015. Stroke: Pathophysiology, Diagnosis, and Management. United States of America: Elsevier.

Harmoko. 2012. Asuhan Keperawatan Keluarga. Yogyakarta : Pustaka Pelajar Harsono. 2007. Kapita Selekta Neurologi. Edisi ke-2. Yogyakarta:Gadjah Mada Univercsity Press, halaman 86-88.

Henderson, S. 2004. The Role Of The Clinical Nurse Specialist In Medical-Surgical Nursing. Medsurg Nursing, 13 (1), 38-41. Hidayat, A. A. 2007. Metode penelitian dan teknik analisis data. Jakarta: Salemba Medika.

Hilton, P. A. 2004. Fundamental Nursing Skills. London and Philadelphia:Whurr Publishers.

Irfan, M. 2012. Fisioterapi Bagi Insan Stroke (Edisi Pertama ed.). Yogyakarta: Graha Ilmu. Javier, Francisco. 2012. Determining Quality Of Life In Stroke Survivors. Expert Rev. Pharmacoecon. Outcomes Res. 12(2), 199-211

Kaakinen. 2015. Family Health Care Nursing: Theory, Practice, and Research. F.A Davis Company. Philadelpia.

Kemenkes. 2014. Profil Kesehatan Indonesia tahun 2014. Kemenkes RI.
Kossasy. 2011. Hubungan Peran Keluarga Dalam Memotivasi Pasien Pasca Stroke Dengan Kepatuhan Penderita Mengikuti Rehabilitasi Di Unit Rehabilitasi Medik. Jurnal Kesehatan STIKes Prima Nusantara Bukittinggi, Vol.6 No 1 Januari 2015

Rumah Sakit Stroke Nasional Bukittinggi Tahun 2014

Langhorne P, Bernhardt J, Kwakkel G. 2011. Stroke Rehabilitation. Elsevier: 377(9778): 1693-702

Levine, P.G. 2011. Stronger After stroke; Panduan Lengkap Dan Efektif Terapi Pemulihan Stroke (Penerjemah oleh Farihah, R.I). Jakarta : Etera.

Lingga, L. 2013. All About Stroke:Hidup Sebelum dan Pasca Stroke. Jakarta:Ele Media Komputindo.

Mansjoer, A., Suprohaita., Wardhani, W.I., \& Setiowulan. 2000.Kapita Selekta Kedokteran Edisi 3 Jilid 2. Jakarta: Media Aesculapius.

Markus, H. d. 2010. Stroke Medicine. New York: Oxford University Press.

Mulyatsih E \& Ahmad A. 2010. Stroke; Petunjuk Perawatan Pasien Pasca Stroke di Rumah. Jakarta: FK Universitas Indonesia.

Mu'tadin, Z. 2002. Pengantar Pendidikan dan IImu Perilaku Kesehatan. Yogyakarta. Andi Offset

National Institute of Neurological Disorders and Stroke. 2009. Brain Basics:Preventing Stroke, (Online),

NINDS, 2015. NINDS Stroke Information Page, (Online), (http://www.ninds.nih.gov/ disorders/stroke/stroke.htm, diakses November 2015). 
Notoatmodjo, S. 2007. Promosi Kesehatan dan Ilmu Perilaku. Jakarta : Rineka Cipta.

Nursalam. 2013. Metodologi Penelitian IImu Keperawatan:Pendekatan Praktis Edisi 3. Jakarta:Salemba Medika

Pertiwi, Intan. 2015. Hubungan Dukungan Pasangan dan Efikasi Diri Dengan Kepatuhan Menjalani Pengobatan pada Penderita Diabetes Mellitus Tipe II. Naskah Publikasi

Pratita, Nurul. 2012. Hubungan Dukungan Pasangan dan Health Locus Of Control dengan Kepatuhan dalam Menjalani Proses Pengobatan pada Penderita Diabetes Melitus Tipe-2. Calyptra: Jurnal Mahasiswa IImiah Universitas Brawijaya Vol 1 No 1

Papalia \& Feldman. 2009. Human development. McGraw-Hill. New york.

Potter, P.A., Perry, A. G. 2009. Fundamental Keperawatan, Edisi 7 Buku 1. Jakarta: Salemba Medika.

Rosamond W, Flegal K, Friday G, Furie K, Go A, Greenlund K, et al. Heart Disease and Stroke Statistics - 2007 update: A report from the American Heart Association statistics committee and stroke statistics subcommittee. Circulation 2007;115(5): e69-e171.

Rosiana, E. 2012. Hubungan Dukungan Keluarga dengan Kepatuhan Menjalani Fisioterapi pada Klien Pasca Stroke di Instalasi Rehabilitasi Medik RSUD Sleman Yogyakarta. Skripsi. Yogyakarta, Universitas Respati: 11-15

Saxena, S. K., Ng, T. P., Yong, D., Fong, N. P., \& Koh, G. 2006. Functional Outcomes In
Inpatient Rehabilitative Care Of Stroke Patients: Predictive Factors And The Effect Of Therapy Intensity. Quality in Primary Care, 14, 145-153.

Setiadi. 2010. Konsep dan Proses Keperawatan Keluarga Edisi kedua. Yogyakarta: Graha Ilmu.

Smeltzer, S. C. B., Brenda. 2002. Buku Ajar Keperawatan Medikal Bedah Brunner \& Suddarth (8 ed.). Jakarta: EGC.

Stroke Association, 2015. Impact of Stroke (Stroke Statistics), (Online), (http:// www.strokeassociation.org/STROKEORG/ AboutStroke/Impact-of-Stroke-Strokestatistics_UCM_310728_Article.jsp\#.VIG6DdLhDIU, diakses November 2015).

Suprajitno, 2004. Asuhan Keperawatan Keluarga. Jakarta: EGC.

Suprobo, Wiyono, Setyanto. 2013. Pengaruh Supportive Group Therapy terhadap Caregiver Burden pada Istri yang berperan sebagai primary caregiver Penderita Stroke di RSUP Dr. Sarjito Yogyakarta. Perpustakaan UNS

Susila, Suryanto. 2015. Metodologi Penelitian Cross Sectional Kedokteran \& Kesehatan. Klaten Selatan:Bossscript

Tamber, S dan Noorkasiani, 2009. Kesehatan Usia Lanjut Dengan Pendekatan Asuhan Keperawatan. Jakarta: Salemba Medika. Walker, T. D. 2012. The Effectiveness of Perceived Social Support and Adherence on Activities of Daily Living Performance $(A D L)$ and Functional Outcomes in First Time Stroke Survivors. Southern University and Agricultural and Mechanical College, United States. 